\title{
Perencanaan Jembatan Beton Prategang Dengan Bentang 24 Meter Berdasarkan Standar Nasional Indonesia (SNI)
}

\author{
Samsuardi BATUBARA ${ }^{1} \cdot$ Larno SIMATUPANG $^{2}$
}

\begin{abstract}
Bridge is used to connect divided road sections, which are seperated by obstacles such as deep valley, river, lake, irigation canals, railway, and also grade seperated roadway. The construction of a bridge must comply with several requirements namely stiffness, deflection, and load bearing requirement. This research is a structural analysis and design of prestressed concrete girder beam with $24 \mathrm{~m}$ length and $6.5 \mathrm{~m}$ width. Working loads are dead load (MS), additional dead load (MA), vehicle load (TD), braking load (TB), pedestrian load (TP), and wind load (EW). Internal forces are obtained using Finite Element Method in SAP2000 nonlinear. Design of the bridge structure follows the national standar SNI 1725:2016 and RSNI T-12-2004. Result of structural design and analysis of the prestressed concrete girder beam uses 4 prestressed beam $(160 \mathrm{~cm}$ height, $1.83 \mathrm{~m}$ distance between beam), $20 \mathrm{~cm}$ bridge slab, and diaphragm with the dimension of $20 \times 165 \times 125 \mathrm{~cm}$. The number of tendon used in the design is 3, and each tendon comprises of 12 strand. The amount of prestressed force caused by jacking is $P_{j}=5351.30 \mathrm{kN}$ with loss prestress $24.52 \%$. Deflection caused on the prestressed beam is $d_{\text {maks }}=12.6 \mathrm{~mm}\left(<d_{i j i n}=80 \mathrm{~mm}\right)$, and occuring stress is $8696 \mathrm{kPa}(<$ allowed stress 18675 $k P a)$.
\end{abstract}

Kata kunci: Jembatan, Beton Prategang, Tendon

\section{Pendahuluan}

Jembatan secara umum berfungsi untuk menghubungkan dua bagian jalan yang terputus oleh suatu rintangan - rintangan seperti lembah yang dalam, alur sungai, danau, saluran irigasi, kali, jalan kereta api dan jalan yang melintang tidak sebidang dan lain - lain. Kehadiran jembatan sangat dibutuhkan guna mempelancar kegiatan sehari-hari. Oleh karena itu, jembatan yang dibangun harus memenuhi syarat kekakuan, lendutan, dan ketahanan terhadap beban yang bekerja. Beragam material menjadi pertimbangan dalam pembuatan jembatan. Material yang umum digunakan dalam pembuatan jembatan bentang panjang biasanya adalah baja dan beton. Namun dalam pemilihan material ada beberapa aspek yang perlu ditinjau yaitu keamanan, harga, waktu pelaksanaan, dan fleksibilitas desain.

Beton adalah material yang kuat dalam kondisi tekan, tetapi lemah dalam kondisi tarik. Kuat tarik beton bervariasi mulai dari $9 \%-15 \%$ dari kuat tekannya. Akibat rendahnya kapasitas tarik tersebut, maka retakan lentur terjadi pada taraf pembebanan yang masih rendah. Oleh karena itu dibutuhkan beton yang dapat menahan gaya tarik yang lebih besar dan dari dimensi penampang lebih kecil sehingga pembuatannya tidak membutuhkan material yang banyak. Salah satu beton yang digunakan dalam pembuatan jembatan adalah beton prategang. Beton prategang adalah beton bertulang yang diberikan gaya pada arah longitudinal elemen struktural. Gaya prategang dapat mencegah berkembangnya retak dengan cara sangat

\footnotetext{
${ }^{1}$ Staf Pengajar Teknik Sipil Universitas Katolik Santo Thomas

e-mail: samsuardi_btbr@yahoo.com

${ }^{2}$ Program Studi Teknik Sipil Universitas Katolik Santo Thomas
} 
mengurangi tegangan tarik di bagian tumpuan dan daerah kritis pada kondisi beban kerja, sehingga dapat meningkatkan kapasitas lentur, geser, dan torsional penampang tersebut. Oleh karena itu penulis melakukan analisis dan merencanakan sebuah jembatan. Jembatan yang direncanakan adalah jembatan beton prategang dengan bentang 24 meter dan lebar 6.5 meter.

\section{Tinjauan Pustaka}

\section{Beban Yang Bekerja Pada Jembatan}

Dalam merencanakan jembatan harus berdasarkan standar yang ditetapkan, dalam hal ini standar yang digunakan adalah SNI 1725:2016 Pembebanan untuk Jembatan. Dalam standar ditetapkan persyaratan minimum untuk pembebanan beserta batasan penggunaan setiap beban, faktor beban dan kombinasi pembebanan yang digunakan untuk perencanaan jembatan jalan raya, termasuk jembatan pejalan kaki serta bangunan sekunder terkait dengan jembatan tersebut.

Beban yang bekerja pada jembatan sangat beragam, seperti berat sendiri jembatan, beban mati tambahan, beban lalu lintas dan beban akibat lingkungan. Berat sendiri adalah berat bagian tersebut dan elemen-elemen struktural lain yang dipikulnya, termasuk dalam hal ini adalah berat bahan dan bagian jembatan yang merupakan elemen struktural, ditambah dengan elemen non-struktural yang dianggap tetap sedangkan Beban mati tambahan adalah berat seluruh bahan yang membentuk suatu beban pada jembatan yang merupakan elemen nonstruktural, dan besarnya dapat berubah selama umur jembatan.

Tabel 1 Berat isi untuk beban mati

\begin{tabular}{|c|c|c|c|}
\hline No. & Bahan & $\begin{array}{l}\text { Berat isi } \\
\left(\mathrm{kN} / \mathrm{m}^{3}\right)\end{array}$ & $\begin{array}{c}\text { Kerapatan massa } \\
\left(\mathrm{kg} / \mathrm{m}^{3}\right)\end{array}$ \\
\hline 1 & $\begin{array}{l}\text { Lapisan permukaan beraspal } \\
\text { (bituminous wearing surfaces) }\end{array}$ & 22.0 & 2245 \\
\hline 2 & Besi tuang (cast iron) & 71.0 & 7240 \\
\hline 3 & $\begin{array}{l}\text { Timbunan tanah dipadatkan } \\
\text { (compacted sand, silt or clay) }\end{array}$ & 17.2 & 1755 \\
\hline 4 & $\begin{array}{l}\text { Kerikil dipadatkan (rolled gravel, } \\
\text { macadam or ballast) }\end{array}$ & $18.8-22.7$ & $1920-2315$ \\
\hline 5 & Beton aspal (asphalt concrete) & 22.0 & 2245 \\
\hline 6 & Beton ringan (low density) & $12.25-19.6$ & $1250-2000$ \\
\hline \multirow{2}{*}{7} & Beton $\quad \mathrm{f}^{\prime} \mathrm{c}<35 \mathrm{Mpa}$ & $22.0-25.0$ & 2320 \\
\hline & $35<\mathrm{f}^{\prime} \mathrm{c}<105 \mathrm{MPa}$ & $22+0.022 \mathrm{f}^{\prime} \mathrm{c}$ & $2240+2.29 \mathrm{f} ' \mathrm{c}$ \\
\hline 8 & Baja (steel) & 78.5 & 7850 \\
\hline 9 & Kayu (ringan) & 7.8 & 800 \\
\hline 10 & Kayu keras (hard wood) & 11.0 & 1125 \\
\hline
\end{tabular}

(Sumber : SNI 1725:2016 Pembebanan untuk Jembatan)

Selain beban mati beban lalu lintas yang melewati jembatan harus diperhitungkan juga. Beban lalu lintas untuk perencanaan jembatan terdiri atas beban lajur "D" dan beban truk "T". Beban lajur "D" bekerja pada seluruh lebar jalur kendaraan dan menimbulkan pengaruh pada jembatan yang ekuivalen dengan suatu iring-iringan kendaraan yang sebenarnya. Jumlah total beban lajur "D" yang bekerja tergantung pada lebar jalur kendaraan itu sendiri. Beban lajur " $\mathrm{D}$ " terdiri atas beban terbagi rata (BTR) yang digabung dengan beban garis (BGT) seperti terlihat dalam Gambar 1. 
Beban terbagi rata (BTR) mempunyai intensitas q $\mathrm{kPa}$ dengan besaran q tergantung pada panjang total yang dibebani L yaitu seperti berikut :

Jika $\mathrm{L} \leq 30 \mathrm{~m}: \mathrm{q}=9.0 \mathrm{kPa}$

Jika $L>30 \mathrm{~m}: \mathrm{q}=9.0\left(0.5+\frac{15}{L}\right)_{\mathrm{kPa}}$

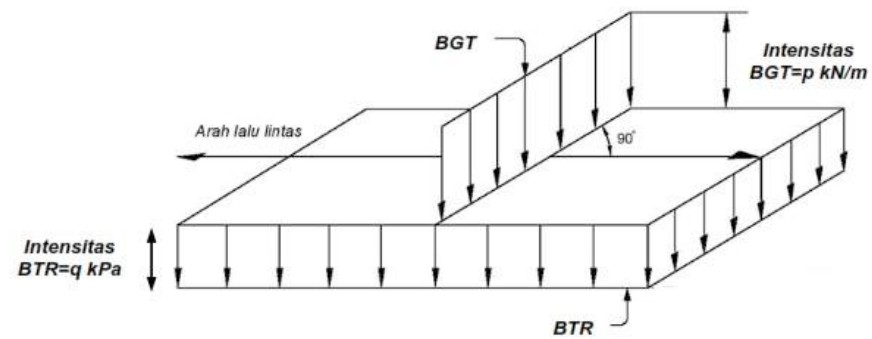

Gambar 1 Beban lajur "D"

Beban garis terpusat (BGT) dengan intensitas $\mathrm{p} \mathrm{kN} / \mathrm{m}$ harus ditempatkan tegak lurus terhadap arah lalu lintas pada jembatan. Besarnya intensitas p adalah 49.0 kN/m. Selain beban "D", terdapat beban lalu lintas lainnya yaitu beban truk "T". Beban truk "T" tidak dapat digunakan bersamaan dengan beban " $D$ ". Beban truk dapat digunakan untuk perhitungan struktur lantai.
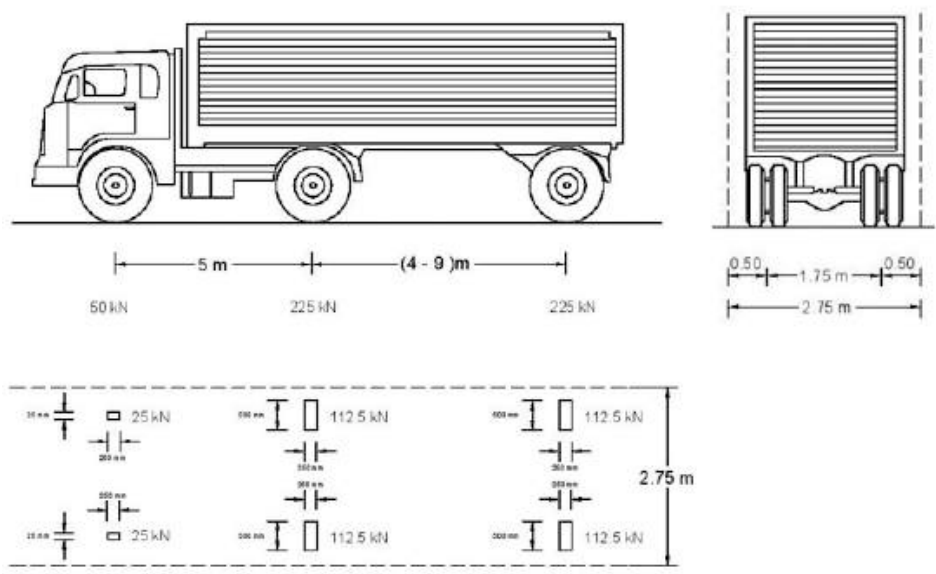

Gambar 2 Pembebanan truk “T” (500 kN)

Pembebanan truk "T" terdiri atas kendaraan truk semi-trailer yang mempunyai susunan dan berat gandar seperti terlihat dalam Gambar 2. Berat dari tiap-tiap gandar disebarkan menjadi 2 beban merata sama besar yang merupakan bidang kontak antara roda dengan permukaan lantai. Jarak antara 2 gandar tersebut bisa diubah-ubah dari $4.0 \mathrm{~m}$ sampai dengan $9.0 \mathrm{~m}$ untuk mendapatkan pengaruh terbesar pada arah memanjang jembatan.

\section{Beton Prategang}

Beton prategang merupakan beton bertulang yang telah diberikan tegangan tekan dalam untuk mengurangi tegangan tarik potensial dalam akibat beban kerja. (SNI 03-2847-2002). Beton prategang juga dapat didefinisikan sebagai beton dimana tegangan tariknya pada kondisi pembebanan tertentu dihilangkan atau dikurangi sampai batas aman dengan 
pemberian gaya tekan permanen, dan baja prategang yang digunakan untuk keperluan ini ditarik sebelum beton mengeras (pratarik) atau setelah beton mengeras (pascatarik).

Seperti yang telah diketahui bahwa beton adalah suatu material yang tahan terhadap tekanan, akan tetapi tidak tahan terhadap tarikan. Sedangkan baja adalah suatu material yang sangat tahan terhadap tarikan. Dengan mengkombinasikan antara beton dan baja dimana beton yang menahan tekanan sedangkan tarikan ditahan oleh baja akan menjadi material yang tahan terhadap tekanan dan tarikan yang dikenal sebagai beton bertulang ( reinforced concrete). Jadi pada beton bertulang, beton hanya memikul tegangan tekan, sedangkan tegangan tarik dipikul oleh baja sebagai penulangan (rebar). Sehingga pada beton bertulang, penampang beton tidak dapat efektif $100 \%$ digunakan, karena bagian yang tertarik tidak diperhitungkan sebagai pemikul tegangan. Hal ini dapat dilihat pada sketsa gambar dibawah ini. Suatu penampang beton bertulang dimana penampang beton yang diperhitungkan untuk memikul tegangan tekan adalah bagian diatas garis netral (bagian yang diarsir), sedangkan bagian dibawah garis netral adalah bagian tarik yang tidak diperhitungkan untuk memikul gaya tarik karena beton tidak tahan terhadap tegangan tarik.

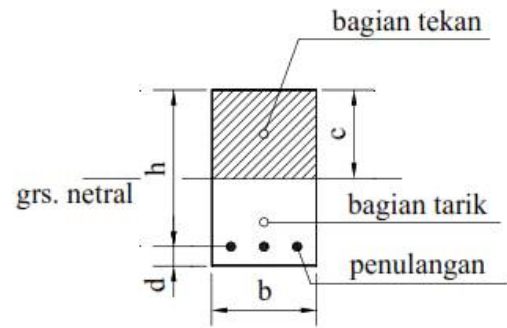

Gambar 3 Distribusi tegangan pada beton

Gaya tarik pada beton bertulang dipikul oleh besi penulangan (rebar). Kelemahan lain dari konstruksi beton bertulang adalah berat sendiri (self weights) yang besar, yaitu 2400 $\mathrm{kg} / \mathrm{m}^{3}$, dapat dibayangkan berapa berat penampang yang tidak diperhitungkan untuk memikul tegangan (bagian tarik). Untuk mengatasi ini pada beton diberi tekanan awal sebelum bebanbeban bekerja, sehingga seluruh penampang beton dalam keadaan tertekan seluruhnya, inilah yang kemudian disebut beton pratekan atau beton prategang (prestressed concrete).

Dengan memberikan tekanan terlebih dahulu (pratekan) pada bahan beton yang pada dasarnya getas akan menjadi bahan yang elastis. Dengan memberikan tekanan (dengan menarik baja mutu tinggi), beton yang bersifat getas dan kuat memikul tekanan, akibat adanya tekanan internal ini dapat memikul tegangan tarik akibat beban eksternal. Hal ini dapat dijelaskan dengan gambar 4.

Akibat diberi gaya tekan (gaya prategang) $\mathrm{F}$ yang bekerja pada pusat berat penampang beton akan memberikan tegangan tekan yang merata diseluruh penampang beton sebaesar F/A, dimana $\mathrm{A}$ adalah luas penampang beton tersebut. Akibat beban merata (termasuk berat sendiri beton) akan memberikan tegangan tarik dibawah garis netral dan tegangan tekan diatas garis netral yang besarnya pada serat terluar penampang adalah : 

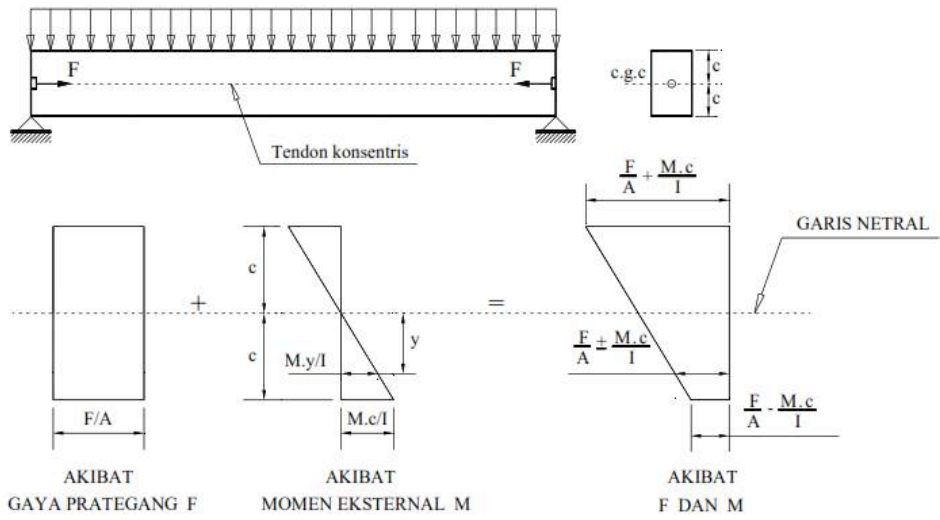

Gambar 4 Konsep prategang menurut Eugene Freyssinet

Tegangan lentur : $\mathrm{f}=\frac{\text { M.c }}{\mathrm{I}}$

Dimana :

M : momen lentur pada penampang yang ditinjau

c : jarak garis netral ke serat terluar penampang

I : momen inersia penampang.

Kalau kedua tegangan akibat gaya prategang dan tegangan akibat momen lentur ini dijumlahkan, maka tegangan maksimum pada serat terluar penampang adalah :

a. Diatas garis netral :

$$
\mathrm{f}_{\text {total }}=\frac{\mathrm{F}}{\mathrm{A}}+\frac{\text { M.c }}{\mathrm{I}} \quad \rightarrow \text { tidak boleh melampaui tegangan hancur beton. }
$$

b. Dibawah garis netral :

$$
\mathrm{f}_{\text {total }}=\frac{\mathrm{F}}{\mathrm{A}}-\frac{\mathrm{M} \cdot \mathrm{c}}{\mathrm{I}} \geq 0 \quad \rightarrow \text { tidak boleh lebih kecil dari nol. }
$$

Jadi dengan adanya gaya internal tekan ini, maka beton akan dapat memikul beban tarik.

\section{Metodologi}

Pada penelitian ini metode yang digunakan adalah dengan berbagai tahapan, yakni dimulai dari pengumpulan data sekunder, studi literatur, analisis pembebanan, analisis kapasitas struktur yang dilakukan dengan bantuan program Microsoft Excel. Perencanaan struktur dilakukan dengan mendesain gelagar jembatan beton prategang dengan acuan pembebanan jembatan berdasarkan SNI 1725:2016 Pembebanan Untuk Jembatan, kombinasi pembebanan terbesar akan digunakan untuk mendesain tulangan lentur dan geser pada jembatan prategang. Perhitungan numerik dilakukan dengan menggunakan bantuan program agar perhitungan dapat terkontrol.

\section{Analisis dan Pembahasan}

\section{Data Jembatan}

Pembahasan berikut ini akan merencanakan gelegar memanjang (girder) pada jembatan 24 meter berdasarkan beban dariSNI 1725:2016 Pembebanan untuk Jembatan. Adapun data jembatan dapat dilihat dibawah ini : 
Panjang bentang jembatan

Tebal slab lantai jembatan

Tebal lapisan aspal + overlay

Tebal genangan air hujan

Jarak antara balok prategang

Lebar jalur lalu-lintas

Lebar trotoar

Lebar total jembatan

$$
\begin{aligned}
\mathrm{L} & =24 \mathrm{~m} \\
\mathrm{~h}_{\mathrm{o}} & =20 \mathrm{~cm} \\
\mathrm{~h}_{\mathrm{a}} & =10 \mathrm{~cm} \\
\mathrm{t}_{\mathrm{h}} & =5 \mathrm{~cm} \\
\mathrm{~s} & =183.30 \mathrm{~cm} \\
\mathrm{~b}_{1} & =550 \mathrm{~cm} \\
\mathrm{~b}_{2} & =50 \mathrm{~cm} \\
\mathrm{~b} & =650 \mathrm{~cm}
\end{aligned}
$$

Balok prategang yang digunakan adalah produk dari PT.Wijaya Karya dengan dimensi yang sudah ada dengan tinggi balok $160 \mathrm{~cm}$. Adapun untuk spesifikasi dimensi yang sudah ada adalah sebagai berikut :

Tabel 2 Dimensi balok prategang

\begin{tabular}{|l|l|l|l|}
\hline Kode & $\begin{array}{c}\text { Lebar } \\
(\mathrm{m})\end{array}$ & Kode & $\begin{array}{c}\text { Tebal } \\
(\mathrm{m})\end{array}$ \\
\hline b1 & 0.550 & h1 & 0.125 \\
\hline b2 & 0.185 & h2 & 0.075 \\
\hline b3 & 0.180 & h3 & 1.250 \\
\hline b4 & 0.235 & h4 & 0.100 \\
\hline b5 & 0.650 & h5 & 0.225 \\
\hline \multicolumn{2}{ll}{} & h & 1.600 \\
\cline { 3 - 4 }
\end{tabular}

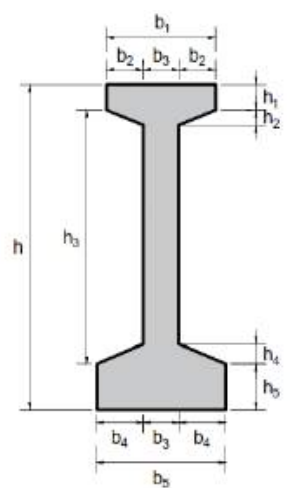

Gambar 6 Dimensi balok prategang

\section{Mutu Beton}

Mutu beton girder prestress : $\mathrm{K}-500$

Kuat tekan beton,

$$
\mathrm{f}_{\mathrm{c}}{ }^{\prime}=0.83 * \mathrm{~K} / 10=41.50 \mathrm{Mpa}
$$

Modulus elastik beton, $\mathrm{E}_{\mathrm{c}}=4700 * \sqrt{ } \mathrm{f}_{\mathrm{c}}{ }^{\prime}=30277.6 \mathrm{Mpa}$

Angka Poisson,

$\mathrm{u}=0.15$

Modulus geser,

$\mathrm{G}=\mathrm{E}_{\mathrm{c}} /[2 *(1+\mathrm{u})]=13164.2 \mathrm{Mpa}$

Koefisien muai panjang untuk beton, $\quad \alpha=10 \times 10^{-6} /{ }^{\circ} \mathrm{C}$

\section{Baja Prategang}

Ada 4 (empat) buah benda uji yakni benda uji tanpa lubang, benda uji dengan lubang 
Tabel 3 Data Strands Cable - Standar VSL

\begin{tabular}{|c|c|c|}
\hline \multicolumn{3}{|c|}{ DATA STRANDS CABLE - STANDAR VSL } \\
\hline \multicolumn{3}{|c|}{ Jenis strands : Uncoated 7 wire super strands ASTM A-416 grade 270} \\
\hline Tegangan leleh strand $\mathrm{f}_{\mathrm{py}}=$ & 1580 & Mpa \\
\hline Kuat tarik strandf $f_{p u}=$ & 1860 & Mpa \\
\hline Diameter nominal strands & 12.7 & $\mathrm{~mm}$ \\
\hline Luas tampang nominal satu strands $\mathrm{A}_{\mathrm{st}}=$ & 98.7 & $\mathrm{~mm}^{2}$ \\
\hline Beban putus minimal satu strands $\mathrm{P}_{\mathrm{bs}}=$ & 187.32 & $(100 \%$ UTS $)$ \\
\hline Jumlah kawat untaian (strands cable) & 12 & kawat untaian / tendon \\
\hline Diameter selubung ideal & 84 & $\mathrm{~mm}$ \\
\hline Luas tampang strands & 1184.4 & $\mathrm{~mm}^{2}$ \\
\hline Beban putus satu tendon $\mathrm{P}_{\mathrm{b} 1}=$ & 2247.8 & $(100 \%$ UTS ) \\
\hline Modulus elastis strands $E_{S}=$ & 193000 & Mpa \\
\hline Tipe dongkrak & VSL19 & \\
\hline
\end{tabular}

\section{Section Properties}

Diambil lebar efektif plat lantai, $\mathrm{B}_{\mathrm{e}}=1.83 \mathrm{~m}$
Kuat tekan beton plat,
$\mathrm{f}_{\mathrm{c}^{\prime} \text { (plat) }}^{\prime}=0.83 * \mathrm{~K}_{\text {(plat) }}$
$\mathrm{f}_{\mathrm{c}^{\prime}(\text { balok })}=0.83 * \mathrm{~K}_{\text {(balok) }}$
$=24.90 \mathrm{Mpa}$
Kuat tekan beton balok,
$\mathrm{E}_{\text {plat }}=4700 * \sqrt{\mathrm{f}_{\mathrm{c}}^{\prime} \text { (plat) }}$
$=41.50 \mathrm{Mpa}$
Modulus elastik plat beton,
Modulus elastik balok beton prategang, $\mathrm{E}_{\text {balok }}=0.043 *\left(\mathrm{~W}_{\mathrm{c}}\right)^{1.5} * \sqrt{ } \mathrm{f}_{\mathrm{c}}{ }^{\prime}($ balok $)=35669.972 \mathrm{Mpa}$
$=23452.95 \mathrm{Mpa}$
Nilai perbandingan modulus elastik plat dan balok, $\quad \mathrm{n}=\mathrm{E}_{\text {plat }} / \mathrm{E}_{\text {balok }}=0.657$
Jadi lebar pengganti beton plat lantai jembatan, $\quad B_{\text {eff }}=n^{*} B_{e}=1.205 m$

Untuk section properties balok prategang dapat dilihat dalam tabel berikut ini :

Tabel 4 Section Properties Balok Prategang

\begin{tabular}{|c|c|c|c|c|c|c|c|}
\hline \multirow[b]{2}{*}{ No. } & \multicolumn{2}{|c|}{ Dimensi } & \multirow{2}{*}{$\begin{array}{c}\text { Luas } \\
\text { Tampang } \\
\text { A } \\
\left(\mathrm{m}^{2}\right)\end{array}$} & \multirow{2}{*}{$\begin{array}{c}\text { Jarak terhadap } \\
\text { Alas } \\
\text { y } \\
\text { (m) }\end{array}$} & \multirow{2}{*}{$\begin{array}{l}\text { Statis } \\
\text { Momen } \\
\text { A*y } \\
\left(\mathrm{m}^{3}\right)\end{array}$} & \multirow{2}{*}{$\begin{array}{l}\text { Inersia } \\
\text { Momen } \\
A * y^{2} \\
\left(m^{4}\right)\end{array}$} & \multirow{2}{*}{$\begin{array}{c}\text { Inersia } \\
\text { Momen } \\
\mathrm{I}_{\mathrm{o}} \\
\left(\mathrm{m}^{4}\right)\end{array}$} \\
\hline & $\begin{array}{c}\text { Lebar } \\
\text { b } \\
(\mathrm{m})\end{array}$ & $\begin{array}{c}\text { Tinggi } \\
\mathrm{h} \\
(\mathrm{m})\end{array}$ & & & & & \\
\hline 1 & 0.550 & 0.125 & 0.0688 & 1.538 & 0.10570 & 0.16252 & 0.000090 \\
\hline 2 & 0.185 & 0.075 & 0.0139 & 1.425 & 0.01977 & 0.02817 & 0.000004 \\
\hline 3 & 0.180 & 1.250 & 0.2250 & 0.850 & 0.19125 & 0.16256 & 0.029297 \\
\hline 4 & 0.235 & 0.100 & 0.0235 & 0.258 & 0.00607 & 0.00157 & 0.000013 \\
\hline 5 & 0.650 & 0.225 & 0.1463 & 0.113 & 0.01645 & 0.00185 & 0.000617 \\
\hline & & Total & 0.4774 & & 0.33925 & 0.35668 & 0.030021 \\
\hline
\end{tabular}

Tinggi total balok prategang :

$$
\begin{aligned}
& \mathrm{h}=1.60 \mathrm{~m} \\
& \mathrm{~A}=0.477 \mathrm{~m}^{2} \\
& \mathrm{y}_{\mathrm{b}}=\Sigma \mathrm{A}^{*} \mathrm{y} / \Sigma \mathrm{A}=0.7107 \mathrm{~m} \\
& \mathrm{~h}_{\mathrm{o}}=0.20 \mathrm{~m} \\
& \mathrm{y}_{\mathrm{a}}=\mathrm{h}-\mathrm{y}_{\mathrm{b}}=0.889 \mathrm{~m}
\end{aligned}
$$

Luas penampang balok prategang :

Momen inersia terhadap alas balok: $\quad \mathrm{I}_{\mathrm{b}}=\Sigma \mathrm{A} * \mathrm{y}+\Sigma \mathrm{I}_{\mathrm{o}}=0.3867 \mathrm{~m}^{4}$

Momen inersia terhadap titik berat balok : $\quad \mathrm{I}_{\mathrm{x}}=\mathrm{I}_{\mathrm{b}}-\mathrm{A} * \mathrm{y}_{\mathrm{b}}{ }^{2}=0.145607 \mathrm{~m}^{4}$

Tahanan momen sisi atas: $\quad \mathrm{W}_{\mathrm{a}}=\mathrm{I}_{\mathrm{x}} / \mathrm{y}_{\mathrm{a}}=0.163724 \mathrm{~m}^{3}$

Tahanan momen sisi bawah: $\quad \mathrm{W}_{\mathrm{b}}=\mathrm{I}_{\mathrm{x}} / \mathrm{y}_{\mathrm{b}}=0.204891 \mathrm{~m}^{3}$ 
Tabel 5 Section Properties Balok Komposit

\begin{tabular}{|c|c|c|c|c|c|c|c|}
\hline \multirow[b]{2}{*}{ No. } & \multicolumn{2}{|c|}{ Dimensi } & \multirow{2}{*}{$\begin{array}{c}\text { Luas } \\
\text { Tampang } \\
\text { A } \\
\left(\mathrm{m}^{2}\right)\end{array}$} & \multirow{2}{*}{$\begin{array}{c}\text { Jarak } \\
\text { terhadap } \\
\text { Alas } \\
\text { y } \\
(\mathrm{m})\end{array}$} & \multirow{2}{*}{$\begin{array}{c}\text { Statis } \\
\text { Momen } \\
\mathrm{A}^{*} \mathrm{y} \\
\left(\mathrm{m}^{3}\right)\end{array}$} & \multirow{2}{*}{$\begin{array}{c}\text { Inersia } \\
\text { Momen } \\
\mathrm{A} * \mathrm{y}^{2} \\
\left(\mathrm{~m}^{4}\right)\end{array}$} & \multirow{2}{*}{$\begin{array}{c}\text { Inersia } \\
\text { Momen } \\
\mathrm{I}_{\mathrm{o}} \\
\left(\mathrm{m}^{4}\right)\end{array}$} \\
\hline & $\begin{array}{c}\text { Lebar } \\
\mathrm{b} \\
(\mathrm{m})\end{array}$ & $\begin{array}{c}\text { Tinggi } \\
\mathrm{h} \\
(\mathrm{m})\end{array}$ & & & & & \\
\hline 0 & 1.205 & 0.200 & 0.2410 & 1.700 & 0.40977 & 0.69660 & 0.000803 \\
\hline 1 & 0.550 & 0.125 & 0.0688 & 1.538 & 0.10570 & 0.16252 & 0.000090 \\
\hline 2 & 0.185 & 0.075 & 0.0139 & 1.425 & 0.01977 & 0.02817 & 0.000004 \\
\hline 3 & 0.180 & 1.250 & 0.2250 & 0.850 & 0.19125 & 0.16256 & 0.029297 \\
\hline 4 & 0.235 & 0.100 & 0.0235 & 0.258 & 0.00607 & 0.00157 & 0.000013 \\
\hline 5 & 0.650 & 0.225 & 0.1463 & 0.113 & 0.01645 & 0.00185 & 0.000627 \\
\hline & & Total : & 0.7184 & & 0.74902 & 1.05328 & 0.030824 \\
\hline
\end{tabular}

Tinggi total balok komposit : $\quad \mathrm{h}_{\mathrm{c}}=1.80 \mathrm{~m}$

Luas penampang balok komposit : $\quad \mathrm{A}_{\mathrm{c}}=0.7184 \mathrm{~m}^{2}$

Letak titik berat :

$$
\begin{aligned}
& \mathrm{y}_{\mathrm{bc}}=\Sigma \mathrm{A}_{\mathrm{c}}{ }^{*} \mathrm{y} / \Sigma \mathrm{A}_{\mathrm{c}}=1.0426 \mathrm{~m} \\
& \mathrm{y}_{\mathrm{ac}}=\mathrm{h}_{\mathrm{c}}-\mathrm{yb}_{\mathrm{c}}=0.7574 \mathrm{~m}
\end{aligned}
$$

Momen inersia terhadap alas balok:

$$
\begin{array}{lll}
\text { Momen inersia terhadap alas balok : } & \mathrm{I}_{\mathrm{bc}}=\Sigma \mathrm{A}_{\mathrm{c}} * \mathrm{y}+\Sigma \mathrm{I}_{\mathrm{co}}=1.084 \mathrm{~m}^{4} \\
\text { Momen inersia terhadap titik berat balok komposit : } & \mathrm{I}_{\mathrm{xc}}=\mathrm{I}_{\mathrm{bc}}-\mathrm{Ac} * \mathrm{y}_{\mathrm{bc}}^{2} & =0.303 \mathrm{~m}^{4}
\end{array}
$$$$
\text { Tahanan momen sisi atas plat: } \mathrm{W}_{\mathrm{ac}}=\mathrm{I}_{\mathrm{xc}} / \mathrm{y}_{\mathrm{ac}} \quad=0.400 \mathrm{~m}^{3}
$$

Tahanan momen sisi atas balok: $\quad \mathrm{W}_{\mathrm{ac}}^{\prime}=\mathrm{I}_{\mathrm{xc}} /\left(\mathrm{y}_{\mathrm{ac}}-\mathrm{h}_{\mathrm{o}}\right) \quad=0.544 \mathrm{~m}^{3}$

Tahanan momen sisi bawah balok: $\quad \mathrm{W}_{\mathrm{bc}}=\mathrm{I}_{\mathrm{xc}} / \mathrm{y}_{\mathrm{bc}}=0.291 \mathrm{~m}^{3}$
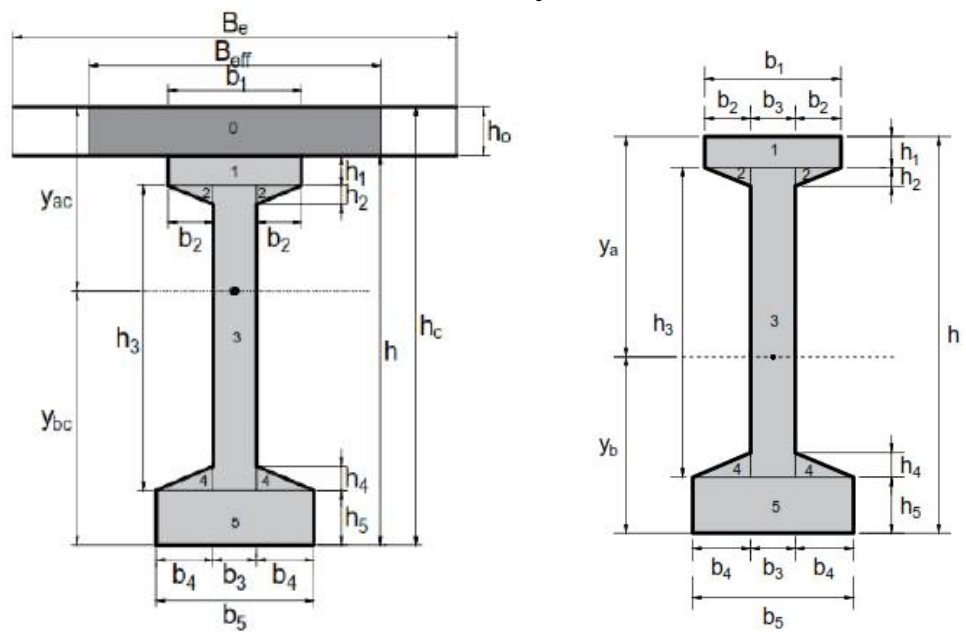

Gambar 7 Section propertiesbalok prategang dan balok komposit

\section{Pembebanan Balok Prategang}

Pembahasan berikut ini akan merencanakan gelegar memanjang (girder) pada jembatan 24 meter berdasarkan beban dariSNI 1725:2016 Pembebanan untuk Jembatan. Adapun data jembatan dapat dilihat dibawah ini :

\section{Berat Sendiri (MS)}

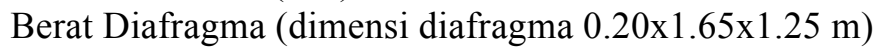

Berat 1 buah diafragma

Jumlah diafragma

$$
\mathrm{W}=10.33 \mathrm{kN}
$$

Berat diafragma,

$\mathrm{n} \quad=7$ buah

$$
\mathrm{W}_{\text {diafragma }} \quad=72.319 \mathrm{kN}
$$


Momen maks di tengah bentang $\mathrm{L}, \quad \mathrm{M}_{\max }=\left(1 / 2 * \mathrm{n}^{*} \mathrm{x}_{3}-\mathrm{x}_{2}-\mathrm{x}_{1}\right) * \mathrm{~W}=309.93 \mathrm{kN} / \mathrm{m}$

Berat diafragma ekuivalen, $\quad \mathrm{Q}_{\text {diafragma }}=8 * \mathrm{M}_{\max } / \mathrm{L}^{2}=4.305 \mathrm{kN} / \mathrm{m}$

Berat Balok Prategang, $\mathrm{W}_{\text {balok }}=\mathrm{A} * \mathrm{~L} * \mathrm{~W}_{\mathrm{c}}=292.2 \mathrm{kN}$ Berat balok prategang $+10 \%$ $\mathrm{Q}_{\text {balok }}=\mathrm{W}_{\text {balok }} / \mathrm{L} \quad=12.173 \mathrm{kN} / \mathrm{m}$

Tabel 6 Gaya Dalam Akibat Berat Sendiri

\begin{tabular}{|c|c|c|c|c|c|c|c|c|}
\hline No. & Jenis beban berat sendiri & $\begin{array}{c}\text { Lebar } \\
\text { b } \\
(\mathrm{m})\end{array}$ & $\begin{array}{c}\text { Tebal } \\
\mathrm{h} \\
(\mathrm{m})\end{array}$ & $\begin{array}{c}\text { Luas } \\
\text { A } \\
\left(\mathrm{m}^{2}\right)\end{array}$ & $\begin{array}{c}\text { Berat sat } \\
\mathrm{w} \\
\left(\mathrm{kN} / \mathrm{m}^{3}\right)\end{array}$ & $\begin{array}{c}\text { Beban } \\
\text { QMs } \\
(\mathrm{kN} / \mathrm{m})\end{array}$ & $\begin{array}{c}\text { Geser } \\
\mathrm{V}_{\mathrm{MS}} \\
(\mathrm{kN})\end{array}$ & $\begin{array}{l}\text { Momen } \\
\mathrm{M}_{\mathrm{MS}} \\
(\mathrm{kNm})\end{array}$ \\
\hline 1 & Balok Prategang & & & & & 12.173 & 146.077 & 876.461 \\
\hline 2 & Plat lantai & 1.833 & 0.20 & 0.367 & 25.00 & 9.165 & 109.980 & 659.880 \\
\hline 3 & Diafragma & & & & & 4.305 & 51.656 & 309.938 \\
\hline & & & & & Total & 25.643 & 307.713 & 1846.278 \\
\hline
\end{tabular}

Beban Mati Tambahan (MA)

Tabel 7 Gaya dalam akibat beban mati tambahan

\begin{tabular}{|c|c|c|c|c|c|c|c|c|}
\hline No. & Jenis beban mati tambahan & $\begin{array}{c}\text { Lebar } \\
\text { B } \\
(\mathrm{m})\end{array}$ & $\begin{array}{c}\text { Tebal } \\
\mathrm{h} \\
(\mathrm{m})\end{array}$ & $\begin{array}{c}\text { Luas } \\
\text { A } \\
\left(\mathrm{m}^{2}\right)\end{array}$ & $\begin{array}{c}\text { Berat sat } \\
\mathrm{w} \\
\left(\mathrm{kN} / \mathrm{m}^{3}\right)\end{array}$ & $\begin{array}{c}\text { Beban } \\
\mathrm{Q}_{\mathrm{MA}} \\
(\mathrm{kN} / \mathrm{m})\end{array}$ & $\begin{array}{l}\text { Geser } \\
\mathrm{V}_{\mathrm{MA}} \\
(\mathrm{kN})\end{array}$ & $\begin{array}{c}\text { Momen } \\
\mathrm{M}_{\mathrm{MA}} \\
(\mathrm{kNm})\end{array}$ \\
\hline 1 & Lapisan aspal + overlay & 1.83 & 0.10 & 0.183 & 22.00 & 4.033 & 48.3912 & 290.3472 \\
\hline 2 & Air hujan & 1.83 & 0.05 & 0.092 & 9.80 & 0.898 & 10.77804 & 64.66824 \\
\hline & & & & & Total : & 4.931 & 59.169 & 355.015 \\
\hline
\end{tabular}

Beban Lajur "D" (TD)

Jarak antara balok prategang,

Beban merata :

$\mathrm{s} \quad=1.83 \mathrm{~m}$

Beban merata pada balok :

$\mathrm{q} \quad=0.8 *(0.5+15 / \mathrm{L})=9.00 \mathrm{kPa}$

Beban garis :

$\mathrm{Q}_{\mathrm{TD}} \quad=\mathrm{q} * \mathrm{~s}=16.50 \mathrm{kN} / \mathrm{m}$

Faktor beban dinamis,

$\mathrm{p} \quad=49.00 \mathrm{kN} / \mathrm{m}$

Beban terpusat pada balok :

DLA $=0.40$

Gaya geser dan momen maksimum pada balok akibat beban lajur " $\mathrm{D}$ " :

$\mathrm{V}_{\mathrm{TD}}=1 / 2 * \mathrm{Q}_{\mathrm{TD}} * \mathrm{~L}+1 / 2 * \mathrm{P}_{\mathrm{TD}} \quad=260.836 \mathrm{kN}$

$\mathrm{M}_{\mathrm{TD}}=1 / 8 * \mathrm{Q}_{\mathrm{TD}} * \mathrm{~L}^{2}+1 / 4 * \mathrm{P}_{\mathrm{TD}} * \mathrm{~L}=1942.247 \mathrm{kNm}$

Gaya Rem (TB)

Gaya rem, $\mathrm{H}_{\mathrm{TB}}=250.00 \mathrm{kN} \quad$ untuk $\mathrm{L} \leq 80 \mathrm{~m}$

Jumlah balok prategang untuk jalur selebar, $\quad \mathrm{n}_{\text {balok }}=4$

Jarak antara balok prategang,

$$
\begin{array}{ll}
\mathrm{s} & =1.833 \mathrm{~m} \\
\mathrm{~T}_{\mathrm{TB}} & =\mathrm{H}_{\mathrm{TB}} / \mathrm{n}_{\text {balok }}=62.50 \mathrm{kN}
\end{array}
$$

Gaya rem, $\quad \mathrm{T}_{\mathrm{TB}}=5 \%$ beban lajur " $\mathrm{D}$ " tanpa faktor beban dinamis,

$$
\begin{aligned}
& \mathrm{Q}_{\mathrm{TD}}=\mathrm{q} * \mathrm{~s}=16.497 \mathrm{kN} / \mathrm{m} \\
& \mathrm{P}_{\mathrm{TD}}=\mathrm{p} * \mathrm{~s}=89.82 \mathrm{kN} \\
& \mathrm{T}_{\mathrm{TB}}=0.05 *\left(\mathrm{Q}_{\mathrm{TD}} * \mathrm{~L}+\mathrm{P}_{\mathrm{TD}}\right)
\end{aligned}
$$

Diambil gaya rem, $\mathrm{T}_{\mathrm{TB}}$

Lengan terhadap Titik berat balok, y

Beban momen akibat gaya rem, M

$$
\begin{array}{ll}
=24.29 \mathrm{kN}<\mathrm{T}_{\mathrm{TB}} & =62.50 \mathrm{kN} \\
= & 62.50 \mathrm{kN} \\
=1.80+\mathrm{h}_{\mathrm{a}}+\mathrm{y}_{\mathrm{ac}} & =2.66 \mathrm{~m} \\
=\mathrm{T}_{\mathrm{TB}} * \mathrm{y} & =166.09 \mathrm{kNm}
\end{array}
$$


Beban Angin (EW)

Beban garis merata tambahan arah horisontal pada permukaan lantai jembatan akibat angin yang meniup kendaraan diatas lantai jembatan dihitung dengan rumus:

$$
\begin{aligned}
\mathrm{T}_{\mathrm{EW}} & =0.0012 * \mathrm{C}_{\mathrm{w}} *\left(\mathrm{~V}_{\mathrm{w}}\right)^{2} \\
& =1.764 \mathrm{kN} / \mathrm{m}
\end{aligned}
$$

Bidang vertikal yang ditiup angin merupakan bidang samping kendaraan dengan

$$
\begin{array}{lll}
\text { tinggi } 2 \mathrm{~m} \text { di atas lantai jembatan. } & \mathrm{h} & =2 \mathrm{~m} \\
\text { Jarak antara roda kendaraan, } & \mathrm{x} & =1.75 \mathrm{~m} \\
\text { Transfer beban angin ke lantai jembatan, } & \mathrm{Q}_{\mathrm{EW}} & =\left[1 / 2 * \mathrm{~h} / \mathrm{x} * \mathrm{~T}_{\mathrm{EW}}\right]=1.008 \mathrm{kN} / \mathrm{m}
\end{array}
$$

Gaya geser dan momen maksimum akibat beban angin :

$$
\begin{array}{ll}
\mathrm{V}_{\mathrm{EW}}=1 / 2 * \mathrm{Q}^{\mathrm{EW}} * \mathrm{~L} & =12.096 \mathrm{kN} \\
\mathrm{M}_{\mathrm{EW}}=1 / 8 * \mathrm{Q}^{\mathrm{EW}} * \mathrm{~L}^{2} & =72.576 \mathrm{kNm}
\end{array}
$$

Beban Gempa (EQ)

Berat sendiri, $\quad \mathrm{Q}_{\mathrm{MS}}=25.643 \mathrm{kN} / \mathrm{m}$

Beban mati tambahan, $\quad \mathrm{Q}_{\mathrm{MA}}=4.931 \mathrm{kN} / \mathrm{m}$

$$
\mathrm{W}_{\mathrm{t}}=\left(\mathrm{Q}_{\mathrm{MS}}+\mathrm{Q}_{\mathrm{MA}}\right) * \mathrm{~L}=733.764 \mathrm{kN}
$$

Koefisien beban gempa horisontal $\mathrm{K}_{\mathrm{h}}=\mathrm{C} * \mathrm{~S}=0.2229$

Koefisien beban gempa vertikal, $\mathrm{K}_{\mathrm{v}}=50 \% * \mathrm{~K}_{\mathrm{h}}=0.1114 \quad>\quad 0.10$

Diambil,$\quad \mathrm{K}_{\mathrm{v}}=0.11$

Gaya gempa vertikal, $\quad \mathrm{T}_{\mathrm{EQ}} \quad=\mathrm{K}_{\mathrm{v}} * \mathrm{~W}_{\mathrm{t}}=81.79639541 \mathrm{kN}$

Beban gempa vertikal, $\quad \mathrm{Q}_{\mathrm{EQ}}=\mathrm{T}_{\mathrm{EQ}} / \mathrm{L}=3.4082 \mathrm{kN} / \mathrm{m}$

Gaya geser dan momen maksimum akibat beban gempa vertikal :

$$
\begin{array}{ll}
\mathrm{V}_{\mathrm{EQ}}=1 / 2 * \mathrm{Q}_{\mathrm{EQ}} * \mathrm{~L} & =40.898 \mathrm{kN} \\
\mathrm{M}_{\mathrm{EQ}}=1 / 8 * \mathrm{Q}_{\mathrm{EQ}} * \mathrm{~L}^{2} & =245.389 \mathrm{kNm}
\end{array}
$$

Berdasarkan perhitungan beban yang bekerja pada jembatan adalah sebagai berikut:

Tabel 8 Resume momen dan gaya geser pada balok

\begin{tabular}{|c|l|c|c|c|c|l|}
\hline No. & \multicolumn{1}{|c|}{ Jenis Beban } & $\begin{array}{c}\text { Kode } \\
\text { beban }\end{array}$ & $\begin{array}{c}\mathrm{Q} \\
(\mathrm{kN} / \mathrm{m})\end{array}$ & $\begin{array}{c}\mathrm{P} \\
(\mathrm{kN})\end{array}$ & $\begin{array}{c}\mathrm{Q} \\
(\mathrm{kNm})\end{array}$ & \multicolumn{1}{|c|}{ Keterangan } \\
\hline 1 & Berat balok prategang & balok & 12.173 & - & - & Beban merata, $\mathrm{Q}_{\text {balok }}$ \\
\hline 2 & Berat plat & plat & 9.165 & - & - & Beban merata, $\mathrm{Q}_{\text {plat }}$ \\
\hline 3 & Berat sendiri & MS & 25.643 & - & - & Beban merata, $\mathrm{Q}_{\mathrm{MS}}$ \\
\hline 4 & Mati Tambahan & MA & 4.931 & - & - & Beban merata, $\mathrm{Q}_{\mathrm{MA}}$ \\
\hline 5 & Lajur "D" & TD & 16.497 & 125.744 & - & Beban merata, $\mathrm{Q}_{\mathrm{MA}}$ \&terpusat, $\mathrm{P}_{\mathrm{TD}}$ \\
\hline 6 & Gaya rem & TB & - & - & 166.088 & Beban momen $\mathrm{M}_{\mathrm{TB}}$ \\
\hline 7 & Angin & EW & 1.008 & - & - & Beban merata \\
\hline 8 & Gempa & EQ & 3.408 & - & - & Beban merata $\mathrm{Q}_{\mathrm{EQ}}$ \\
\hline
\end{tabular}

\section{Momen Pada Balok Prategang}

Analisis momen yang terjadi pada balok prategang dapat dilihat pada tabel yang disajikan berikut ini. 
Tabel 9 Momen Pada Balok Prategang

\begin{tabular}{|c|c|c|c|c|c|c|c|c|c|c|c|}
\hline \multirow{3}{*}{$\begin{array}{c}\text { Jarak } \\
\mathrm{X}\end{array}$} & \multicolumn{7}{|c|}{ Momen pada balok prategang akibat beban } & \multirow{3}{*}{$\begin{array}{c}\text { KOMB I } \\
\mathrm{MS}+\mathrm{MA}+ \\
\mathrm{TD}+\mathrm{TB}\end{array}$} & \multirow{3}{*}{$\begin{array}{c}\text { KOMB II } \\
\mathrm{MS}+\mathrm{MA}+ \\
\mathrm{TD}+\mathrm{EW}\end{array}$} & \multirow{3}{*}{$\begin{array}{c}\text { KOMB III } \\
\mathrm{MS}+\mathrm{MA}+\mathrm{TD} \\
+\mathrm{TB}+\mathrm{EW} \\
\end{array}$} & \multirow{3}{*}{$\frac{\text { KOMB IV }}{\text { MS+MA+EQ }}$} \\
\hline & \multirow{2}{*}{$\begin{array}{l}\text { Berat } \\
\text { balok }\end{array}$} & \multirow{2}{*}{$\begin{array}{c}\text { Berat sen } \\
\text { MS }\end{array}$} & \multirow{2}{*}{$\begin{array}{c}\text { Mati tamb } \\
\text { MA }\end{array}$} & \multirow{2}{*}{$\begin{array}{c}\text { Lajur "D" } \\
\text { TD }\end{array}$} & \multirow{2}{*}{$\begin{array}{c}\text { Rem } \\
\text { TB } \\
\end{array}$} & \multirow{2}{*}{$\begin{array}{c}\text { Angin } \\
\text { EW }\end{array}$} & \multirow{2}{*}{$\begin{array}{c}\text { Gempa } \\
\text { EQ }\end{array}$} & & & & \\
\hline & & & & & & & & & & & \\
\hline$(\mathrm{m})$ & $(\mathrm{kNm})$ & $(\mathrm{kNm})$ & $(\mathrm{kNm})$ & $(\mathrm{kNm})$ & $(\mathrm{kNm})$ & $(\mathrm{kNm})$ & $(\mathrm{kNm})$ & $(\mathrm{kNm})$ & $(\mathrm{kNm})$ & $(\mathrm{kNm})$ & $(\mathrm{kNm})$ \\
\hline 0.0 & 0.00 & 0.00 & 0.00 & 0.00 & 0.00 & 0.00 & 0.00 & 0.00 & 0.00 & 0.00 & 0.00 \\
\hline 1.0 & 139.99 & 294.89 & 56.70 & 252.59 & 6.92 & 11.59 & 39.19 & 611.10 & 615.77 & 622.70 & 390.79 \\
\hline 2.0 & 267.81 & 564.14 & 108.48 & 488.68 & 13.84 & 22.18 & 74.98 & 1175.14 & 1183.47 & 1197.31 & 747.60 \\
\hline 3.0 & 383.45 & 807.75 & 155.32 & 708.27 & 20.76 & 31.75 & 107.36 & 1692.10 & 1703.09 & 1723.85 & 1070.42 \\
\hline 4.0 & 486.92 & 1025.71 & 197.23 & 911.37 & 27.68 & 40.32 & 136.33 & 2161.99 & 2174.63 & 2202.31 & 1359.27 \\
\hline 5.0 & 578.22 & 1218.03 & 234.21 & 1097.97 & 34.60 & 47.88 & 161.89 & 2584.81 & 2598.09 & 2632.69 & 1614.13 \\
\hline 6.0 & 657.35 & 1384.71 & 266.26 & 1268.07 & 41.52 & 54.43 & 184.04 & 2960.56 & 2973.47 & 3014.99 & 1835.01 \\
\hline 7.0 & 724.30 & 1525.74 & 293.38 & 1421.67 & 48.44 & 59.98 & 202.79 & 3289.24 & 3300.78 & 3349.22 & 2021.91 \\
\hline 8.0 & 779.08 & 1641.14 & 315.57 & 1558.78 & 55.36 & 64.51 & 218.12 & 3570.85 & 3580.00 & 3635.36 & 2174.83 \\
\hline 9.0 & 821.68 & 1730.89 & 332.83 & 1679.39 & 62.28 & 68.04 & 230.05 & 3805.39 & 3811.15 & 3873.43 & 2293.76 \\
\hline 10.0 & 852.11 & 1794.99 & 345.15 & 1783.51 & 69.20 & 70.56 & 238.57 & 3992.86 & 3994.22 & 4063.42 & 2378.72 \\
\hline 11.0 & 870.37 & 1833.46 & 352.55 & 1871.13 & 76.12 & 72.07 & 243.69 & 4133.26 & 4129.21 & 4205.33 & 2429.69 \\
\hline 12.0 & 876.46 & 1846.28 & 355.02 & 1942.25 & 83.04 & 72.58 & 245.39 & 4226.58 & 4216.12 & 4299.16 & 2446.68 \\
\hline
\end{tabular}

\section{Gaya Prategang, Eksentrisitas, dan Jumlah Tendon}

Mutu beton girder prestress : $\mathrm{K}-500$

Kuat tekan beton, $\quad \mathrm{f}_{\mathrm{c}}{ }^{\prime}=0.83 * \mathrm{~K} * 100=41500 \mathrm{kPa}$

Kuat tekan beton pada keadaan awal (saat transfer), $\quad \mathrm{f}_{\mathrm{ci}}{ }^{\prime}=0.80 * \mathrm{f}_{\mathrm{c}}{ }^{\prime}=33200 \mathrm{kPa}$

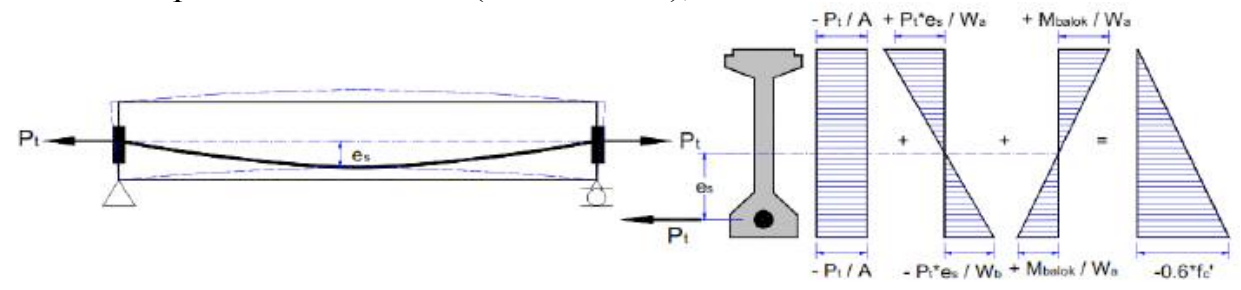

Gambar 8 Gaya prategang pada balok

Ditetapkan jarak titik berat tendon terhadap alas balok, $\mathrm{z}_{0}=0.175 \mathrm{~m}$

Eksentrisitas tendon, $\quad \mathrm{e}_{\mathrm{s}}=\mathrm{y}_{\mathrm{b}}-\mathrm{z}_{0}=0.536 \mathrm{~m}$

Momen akibat berat sendiri balok, $\quad \mathrm{M}_{\text {balok }}=876.46 \mathrm{kN} / \mathrm{m}$

Tegangan di serat atas,

$0=-\mathrm{P}_{\mathrm{t}} / \mathrm{A}+\mathrm{P}_{\mathrm{t}} * \mathrm{e}_{\mathrm{s}} / \mathrm{W}_{\mathrm{a}}-\mathrm{M}_{\text {balok }} / \mathrm{W}_{\mathrm{a}}$

Tegangan di serat bawah,

$0.6^{*} \mathrm{f}_{\mathrm{ci}}{ }^{\prime}=-\mathrm{P}_{\mathrm{t}} / \mathrm{A}-\mathrm{P}_{\mathrm{t}} * \mathrm{e}_{\mathrm{s}} / \mathrm{W}_{\mathrm{b}}+\mathrm{M}_{\mathrm{balok}} / \mathrm{W}_{\mathrm{b}}$

Besarnya gaya prategang awal,

Dari persamaan (2): $\quad \mathrm{P}_{\mathrm{t}}=\mathrm{M}_{\text {balok }} /\left(\mathrm{e}_{\mathrm{s}}-\mathrm{W}_{\mathrm{a}} / \mathrm{A}\right)=4548.6 \mathrm{kN}$

Dari persamaan (3): $\quad \mathrm{P}_{\mathrm{t}}=\left[0.60 * \mathrm{f}_{\mathrm{ci}}{ }^{\prime} * \mathrm{~W}_{\mathrm{b}}+\mathrm{M}_{\mathrm{balok}}\right] /\left(\mathrm{W}_{\mathrm{b}} / \mathrm{A}+\mathrm{e}_{\mathrm{s}}\right)=5138.465 \mathrm{kN}$

Diambil besarnya gaya prategang, $\quad \mathrm{P}_{\mathrm{t}}=4548.6 \mathrm{kN}$

Beban putus satu tendon, $\quad \mathrm{P}_{\mathrm{b} 1}=2247.88 \mathrm{kN}$

Beban putus minimal satu strand, $\quad \mathrm{P}_{\mathrm{bs}}=187.32 \mathrm{kN}$

$\begin{array}{lll}\text { Gaya prategang saat jacking: } & \mathrm{P}_{\mathrm{j}}=\mathrm{P}_{\mathrm{t} 1} / 0.85 & \text { persamaan (1) } \\ & \mathrm{P}_{\mathrm{j}}=0.80 * \mathrm{P}_{\mathrm{b} 1} * \mathrm{n}_{\mathrm{t}} & \text { persamaan }(2)\end{array}$

$$
\mathrm{P}_{\mathrm{j}}=0.80 * \mathrm{P}_{\mathrm{b} 1} * \mathrm{n}_{\mathrm{t}} \quad \text { persamaan (2) }
$$

Dari persamaan (2) dan (3) diperoleh jumlah tendon yang diperlukan :

$\mathrm{n}_{\mathrm{t}}=\mathrm{P}_{\mathrm{t}} /\left(0.85^{*} 0.80^{*} \mathrm{P}_{\mathrm{b} 1}\right)=2.975$ Tendon $\rightarrow$ Jumlah tendon, $\mathrm{n}_{\mathrm{t}}=3$ Tendon

Jumlah kawat untaian (strands cable) yang diperlukan,

$\mathrm{n}_{\mathrm{s}}=\mathrm{P}_{\mathrm{t}} /\left(0.85^{*} 0.80 * \mathrm{P}_{\mathrm{bs}}\right)=35.709$ Strands $\rightarrow$ Digunakan $\mathrm{n}_{\mathrm{s}}=36$ Strands

Persentase tegangan leleh yang timbul pada baja ( \% Jacking Force) :

$\mathrm{p}_{\mathrm{o}}=\mathrm{P}_{\mathrm{t}} /\left(0.85 * \mathrm{n}_{\mathrm{s}} * \mathrm{P}_{\mathrm{bs}}\right) * 100 \%=79.35 \% \quad<\mathbf{8 0 \%}(\mathbf{O K})$ 
Gaya prategang yang terjadi akibat jacking :

$\mathrm{P}_{\mathrm{j}}=\mathrm{p}_{\mathrm{o}} * \mathrm{n}_{\mathrm{s}} * \mathrm{P}_{\mathrm{bs}}=5351.295 \mathrm{kN}$

Diperkirakan kehilangan tegangan ( loss of prestress ) $=30 \%$

Gaya prategang akhir setelah kehilangan tegangan (loss of prestress) sebesar 30\%:

$\mathrm{P}_{\text {eff }}=70 \% * \mathrm{P}_{\mathrm{j}}=3745.906 \mathrm{kN}$

\section{Lintasan Inti Tendon (Cable)}

Eksentrisitas, $\mathrm{e}_{\mathrm{s}}=0.536 \mathrm{~m}$

Persamaan lintasan tendon: $\quad \mathrm{Y}=4 * \mathrm{f} * \mathrm{X} / \mathrm{L}^{2} *(\mathrm{~L}-\mathrm{X}) \quad$ dengan, $\mathrm{f}=\mathrm{e}_{\mathrm{s}}$

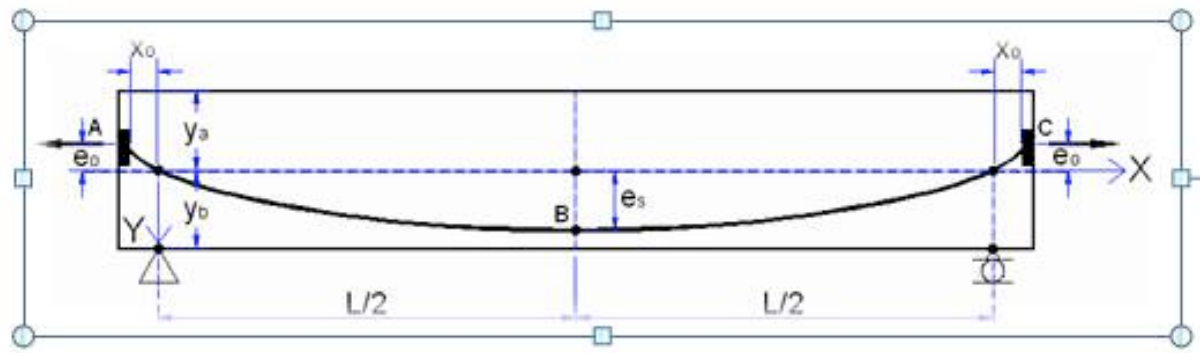

Gambar 9 Persamaan Lintasan tendon

Berdasarkan persamaan lintasan tendon di atas diperoleh lintasan tendon seperti pada grafik berikut ini :

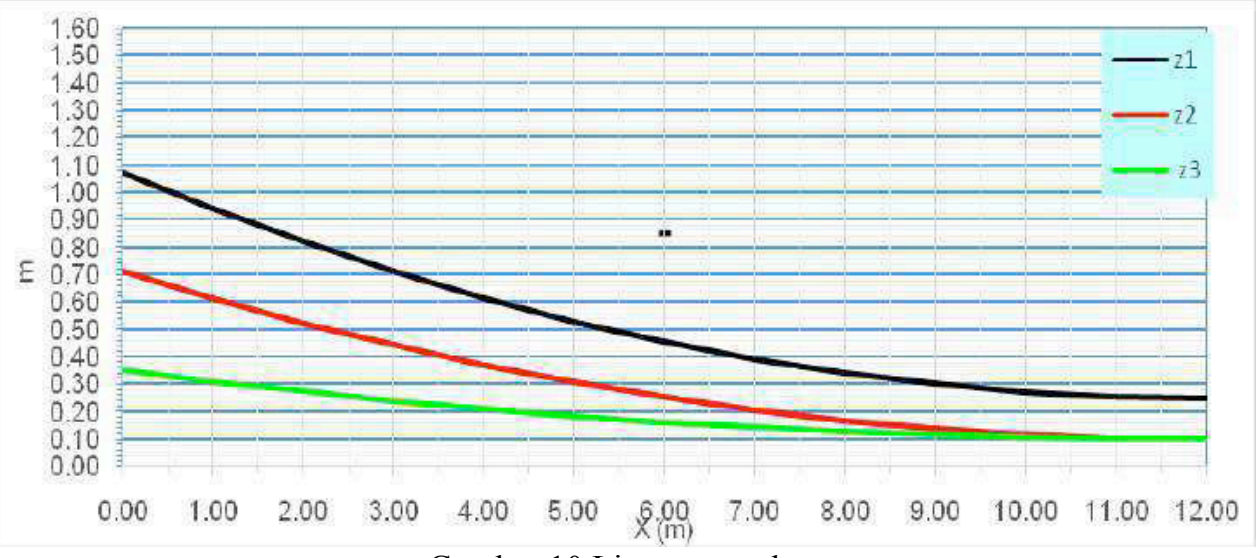

Gambar 10 Lintasan tendon

\section{Kehilangan Gaya Prategang}

Dari hasil perhitungan diperoleh kehilangan gaya prategang yang terjadi akibat berbagai faktor adalah sebesar $25.52 \%$ dari Gaya prategang yang terjadi akibat jacking, berikut adalah tabel kehilangan gaya prategang.

Tabel 10 Kehilangan gaya prategang

\begin{tabular}{|l|l|l|l|}
\hline Gaya & $(\mathrm{kN})$ & Loss of prestress & $\%$ UTS \\
\hline $\mathrm{P}_{\mathrm{j}}$ & 5351.30 & Anchorage friction & $79.35 \%$ \\
\hline $\mathrm{P}_{\mathrm{o}}$ & 5190.76 & Jack friction & $76.97 \%$ \\
\hline $\mathrm{P}_{\mathrm{x}}$ & 4858.33 & Elastic shortening & $72.04 \%$ \\
\hline $\mathrm{P}_{\mathrm{i}}$ & 4644.90 & Relaxation of tendon & $68.88 \%$ \\
\hline $\mathrm{P}_{\mathrm{eff}}$ & 4039.06 & Prategang Efektif & $59.90 \%$ \\
\hline
\end{tabular}




\section{Tegangan Yang Terjadi}

Tegangan pada saat transfer

Mutu beton balok prategang $=\mathrm{K}-500$

Kuat tekan beton, $\mathrm{f}_{\mathrm{c}}{ }^{\prime}=0.83 * \mathrm{~K} * 100=41500 \mathrm{kPa}$

Kuat tekan beton pada kondisi awal (saat transfer), $\mathrm{f}_{\mathrm{ci}}{ }^{\prime}=0.80 * \mathrm{f}_{\mathrm{c}}{ }^{\prime}=33200 \mathrm{kPa}$

Tegangan ijin tekan beton, $-0.6 * \mathrm{f}_{\mathrm{ci}}{ }^{\prime}=-19920 \mathrm{kPa}$

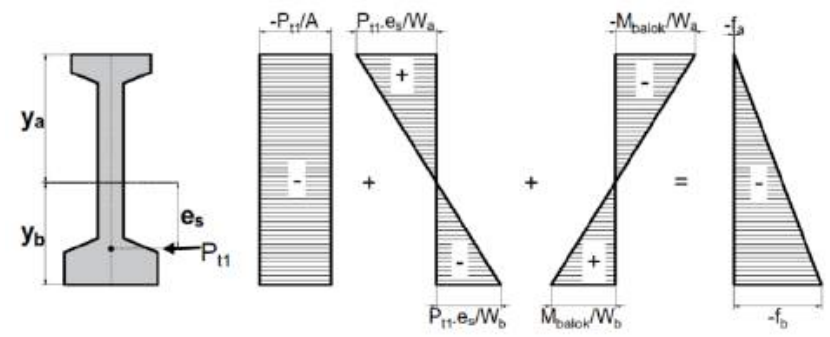

Gambar 11 Tegangan pada balok keadaan saat transfer

Tegangan di serat atas, $\mathrm{f}_{\mathrm{ca}} \quad=-\mathrm{P}_{\mathrm{t}} / \mathrm{A}+\mathrm{P}_{\mathrm{t}} * \mathrm{e}_{\mathrm{s}} / \mathrm{W}_{\mathrm{a}}-\mathrm{M}_{\mathrm{balok}} / \mathrm{W}_{\mathrm{a}}=0.000 \mathrm{kPa}$

Tegangan di serat bawah, $\mathrm{f}_{\mathrm{cb}}=-\mathrm{P}_{\mathrm{t}} / \mathrm{A}-\mathrm{P}_{\mathrm{t}} * \mathrm{e}_{\mathrm{s}} / \mathrm{W}_{\mathrm{b}}+\mathrm{M}_{\mathrm{balok}} / \mathrm{W}_{\mathrm{b}}$

$$
=-17142 \mathrm{kPa}<-0.6^{*} \mathrm{f}_{\mathrm{ci}}{ }^{\prime}(\text { Aman })
$$

Tegangan beton pada kondisi beban layan (setelah memperhitungkan semua kehilangan tegangan) tidak boleh melebihi nilai sebagai berikut :

Tegangan ijin tekan beton, $\quad \mathrm{F}_{\mathrm{c}}{ }^{\prime}=-0.45 * \mathrm{f}_{\mathrm{c}}{ }^{\prime} \quad=-18675 \mathrm{kPa}$

Tegangan ijin tarik beton, $\quad F_{c}=-0.50 * \sqrt{ } f_{c}{ }^{\prime}=102 \mathrm{kPa}$

Tegangan akibat berat sendiri (MS)

Tegangan beton di serat atas plat, $\quad \mathrm{f}_{\mathrm{ac}}=-\mathrm{M}_{\mathrm{MS}} / \mathrm{W}_{\mathrm{ac}} \quad=-4612.34 \mathrm{kPa}$

Tegangan beton di serat atas balok, $\quad \mathrm{f}_{\mathrm{ac}}^{\prime}=-\mathrm{M}_{\mathrm{MS}} / \mathrm{W}_{\mathrm{ac}}^{\prime} \quad=-3394.41 \mathrm{kPa}$

Tegangan di serat bawah balok, $\quad \mathrm{f}_{\mathrm{bc}}=\mathrm{M}_{\mathrm{MS}} / \mathrm{W}_{\mathrm{bc}}=6349.058 \mathrm{kPa}$

Tegangan akibat beban mati tambahan (MA)

Tegangan beton di serat atas plat, $\quad \mathrm{f}_{\mathrm{ac}}=-\mathrm{M}_{\mathrm{MS}} / \mathrm{W}_{\mathrm{ac}} \quad=-886.893 \mathrm{kPa}$

Tegangan beton di serat atas balok, $\quad \mathrm{f}_{\mathrm{ac}}^{\prime}=-\mathrm{M}_{\mathrm{MS}} / \mathrm{W}^{\prime}{ }_{\mathrm{ac}} \quad=-652.701 \mathrm{kPa}$

Tegangan di serat bawah balok, $\quad \mathrm{f}_{\mathrm{bc}}=\mathrm{M}_{\mathrm{MS}} / \mathrm{W}_{\mathrm{bc}}=1220.842 \mathrm{kPa}$

Tegangan akibat prategang (PR)

Tegangan beton di serat atas plat, $\mathrm{f}_{\mathrm{ac}}=-\mathrm{P}_{\text {eff }} / \mathrm{A}_{\mathrm{c}}+\mathrm{P}_{\text {eff }} * \mathrm{e}_{\mathrm{s}} \mathrm{s}_{\mathrm{s}} / \mathrm{W}_{\mathrm{ac}}=3132 \mathrm{kPa}$

Tegangan beton di serat atas balok, $\mathrm{f}_{\mathrm{ac}}=-\mathrm{P}_{\text {eff }} / \mathrm{A}_{\mathrm{c}}+\mathrm{P}_{\text {eff }} * \mathrm{e}_{\mathrm{s}}^{\prime} / \mathrm{W}_{\mathrm{ac}}=820 \mathrm{kPa}$

Tegangan di serat bawah bawah, $\mathrm{f}_{\mathrm{bc}}=-\mathrm{P}_{\mathrm{eff}} / \mathrm{A}_{\mathrm{c}}-\mathrm{P}_{\mathrm{eff}} * \mathrm{e}_{\mathrm{s}}^{\prime} / \mathrm{W}_{\mathrm{bc}}=-17673 \mathrm{kPa}$

Tegangan akibat beban lajur "D" (TD)

Tegangan beton di serat atas plat, $\mathrm{f}_{\mathrm{ac}}=\mathrm{f}_{\mathrm{ac}}=-\mathrm{M}_{\mathrm{TD}} / \mathrm{W}_{\mathrm{ac}}=-4852 \mathrm{kPa}$

Tegangan beton di serat atas balok, $\mathrm{f}_{\mathrm{ac}}^{\prime}=\mathrm{f}_{\mathrm{ac}}=-\mathrm{M}_{\mathrm{TD}} / \mathrm{W}_{\mathrm{ac}}^{\prime}=-3571 \mathrm{kPa}$

Tegangan di serat bawah bawah, $\mathrm{f}_{\mathrm{bc}} \quad=\mathrm{f}_{\mathrm{bc}}=\mathrm{M}_{\mathrm{TD}} / \mathrm{W}_{\mathrm{bc}} \quad=6679 \mathrm{kPa}$

Tabel 11. Tegangan maksimum terjadi pada kombinasi 4

\begin{tabular}{|c|c|c|c|c|c|c|c|c|c|c|c|}
\hline \multirow{3}{*}{$\begin{array}{l}\text { Tega } \\
\text { ngan }\end{array}$} & \multicolumn{9}{|c|}{ Tegangan pada beton yang terjadi akibat beban } & \multirow{2}{*}{$\begin{array}{l}\text { Tega } \\
\text { ngan }\end{array}$} & \multirow{3}{*}{ Keterengan } \\
\hline & Berat Sen & Mati Tamb & Susut-Rang & Prategans & Lajur "D" & Rem & Temperatur & Angin & Gempa & & \\
\hline & MS & MA & SR & PR & TD & TB & ET & EW & EQ & KOMB & \\
\hline$f_{a c}$ & -4612 & -887 & -557 & 3132 & -4852 & 207 & -531 & -181 & & -8696 & $<\mathrm{F}_{\mathrm{c}}^{\prime}($ Aman $)$ \\
\hline $\mathrm{f}_{\mathrm{ac}}^{\prime}$ & -3394 & -653 & 45 & 820 & -3571 & -153 & -981 & -133 & & -8020 & $<\mathrm{F}_{\mathrm{c}}^{\prime}($ Aman $)$ \\
\hline $\mathrm{f}_{\mathrm{bc}}$ & 6349 & 1221 & 748 & -17673 & 6679 & 286 & -711 & 250 & & -2851 & $<\mathbf{F}_{\mathrm{c}}^{\prime}($ Aman $)$ \\
\hline
\end{tabular}




\section{Lendutan Yang Terjadi Pada Balok}

Lendutan Pada Balok Prestress (Sebelum Composit)

$$
\begin{array}{ll}
\mathrm{E}_{\text {balok }} & =3.57 . \mathrm{E}+07 \mathrm{kPa} \\
\mathrm{I}_{\mathrm{x}} & =0.1456 \mathrm{~m}^{4} \\
\mathrm{~L} & =24.00 \mathrm{~m}
\end{array}
$$

Lendutan pada keadaan awal (transfer)

$$
\begin{aligned}
& \mathrm{d}=5 / 384 *\left(-\mathrm{Q}_{\mathrm{pt} 1}+\mathrm{Q}_{\text {balok }}\right) * \mathrm{~L}^{4} /\left(\mathrm{E}_{\text {balok }} * \mathrm{I}_{\mathrm{x}}\right) \quad=-0.018 \mathrm{~m} \quad \text { ke atas }<\mathbf{L} / 240 \text { (OK) } \\
& \text { Lendutan setelah loss of prestress } \\
& \mathrm{d}=5 / 384 *\left(-\mathrm{Q}_{\text {peff }}+\mathrm{Q}_{\text {balo }} \mathrm{k}\right) * \mathrm{~L}^{4} /\left(\mathrm{E}_{\text {balok }} * \mathrm{I}_{\mathrm{x}}\right)=-0.015 \mathrm{~m} \quad \text { ke } \operatorname{atas}<\mathbf{L} / \mathbf{2 4 0}(\mathbf{O K}) \\
& \text { Lendutan Setelah Plat Dan Balok Menjadi Komposit } \\
& \mathrm{d}=5 / 384 *\left(-\mathrm{Q}_{\text {peff }}+\mathrm{Q}_{\text {balok }+ \text { plat }}\right) * \mathrm{~L}^{4} /\left(\mathrm{E}_{\text {balok }} * \mathrm{I}_{\mathrm{xc}}\right)=-0.011 \mathrm{~m} \quad \text { ke atas }<\mathbf{L} / \mathbf{2 4 0}(\mathbf{O K}) \\
& \mathrm{E}_{\text {balok }}=3.57 . \mathrm{E}+07 \mathrm{kPa} \\
& \mathrm{I}_{\mathrm{xc}}=0.303 \mathrm{~m}^{4} \\
& \mathrm{~L}=24.00 \mathrm{~m} \\
& \mathrm{e}_{\mathrm{s}}=0.53566 \mathrm{~m} \\
& \mathrm{P}_{\text {eff }}=4039.06 \mathrm{kN} \\
& \mathrm{e}_{\mathrm{s}}^{\prime}=0.867596 \mathrm{~m} \\
& \mathrm{~d}=\mathrm{L} / 300=0.0800 \mathrm{~m}
\end{aligned}
$$

Lendutan akibat berat sendiri (MS)

$\mathrm{d}=5 / 384 * \mathrm{Q}_{\mathrm{MS}} * \mathrm{~L}^{4} /\left(\mathrm{E}_{\text {balok }} * \mathrm{I}_{\mathrm{xc}}\right)=0.01024 \mathrm{~m}$

ke bawah

Lendutan akibat beban mati tambahan (MA)

\begin{tabular}{|c|c|c|c|c|c|c|c|c|c|c|c|}
\hline \multirow{3}{*}{ d } & \multicolumn{10}{|c|}{ Lendutan $(\mathrm{m})$ pada balok komposit beban } & \multirow{3}{*}{ Keterangan } \\
\hline & Berat Sen & Mati Tamb & Sust-Rang & Prategang & Lajur "D" & Rem & Temperatur & Angin & Gempa & Lendutan & \\
\hline & MS & MA & $\mathrm{SR}$ & PR & TD & TB & ET & EW & EQ & KOMB & \\
\hline \multicolumn{12}{|c|}{ KOMBINASI - 1} \\
\hline $\mathrm{d}(\mathrm{m})$ & 0.01140 & 0.00219 & -0.00272 & -0.00955 & 0.011 & 0.00063 & & & & 0.00984 & $<L / 300$ \\
\hline \multicolumn{12}{|c|}{ KOMBINASI - 2} \\
\hline $\mathrm{d}(\mathrm{m})$ & 0.01140 & 0.00219 & -0.00272 & -0.00955 & 0.011 & 0.00063 & 0.00233 & & & 0.01218 & $<L / 300$ \\
\hline \multicolumn{12}{|c|}{ KOMBINASI - 3} \\
\hline$d(\mathrm{~m})$ & 0.01140 & 0.00219 & -0.00272 & -0.00955 & 0.011 & 0.00063 & & 0.00040 & & 0.01025 & $<L / 300$ \\
\hline \multicolumn{12}{|c|}{ KOMBINASI - 4} \\
\hline $\mathrm{d}(\mathrm{m})$ & 0.01140 & 0.00219 & -0.00272 & -0.00955 & 0.011 & 0.00063 & 0.00233 & 0.00040 & & 0.01258 & $<L / 300$ \\
\hline \multicolumn{12}{|c|}{ KOMBINASI - 5} \\
\hline$d(m)$ & 0.01140 & 0.00219 & -0.00272 & -0.00955 & & & & & 0.0013 & 0.00070 & $<L / 300$ \\
\hline
\end{tabular}

$\mathrm{d}=5 / 384 * \mathrm{Q}_{\mathrm{MA}} * \mathrm{~L}^{4} /\left(\mathrm{E}_{\text {balok }} * \mathrm{I}_{\mathrm{xc}}\right)=0.00197 \mathrm{~m} \quad$ ke bawah

Lendutan akibat prestress (PR)

$\mathrm{d}=5 / 384 *-\mathrm{Q}_{\text {eff }} * \mathrm{~L}^{4} /\left(\mathrm{E}_{\text {balok }} * \mathrm{I}_{\mathrm{xc}}\right)=-0.01200 \mathrm{~m} \quad$ ke atas

Lendutan akibat beban lajur "D" (TD)

$\mathrm{d}=1 / 48 * \mathrm{P}_{\mathrm{TD}} * \mathrm{~L}^{3} /\left(\mathrm{E}_{\text {balok }} * \mathrm{I}_{\mathrm{xc}}\right)+5 / 384 * \mathrm{Q}_{\mathrm{TD}} * \mathrm{~L}^{4} /\left(\mathrm{E}_{\text {balok }} * \mathrm{I}_{\mathrm{xc}}\right)=0.00994 \mathrm{~m} \quad$ ke bawah Lendutan akibat beban rem (TB)

$\mathrm{d}=0.0642 * \mathrm{Q}_{\mathrm{TB}} * \mathrm{~L}^{2} /\left(\mathrm{E}_{\text {balok }} * \mathrm{I}_{\mathrm{xc}}\right) \quad=0.00057 \mathrm{~m} \quad$ ke bawah

Lendutan akibat pengaruh temperatur (ET)

$\mathrm{d}=0.0642 * \mathrm{SP}_{\mathrm{t}} * \mathrm{e}_{\mathrm{p}} * \mathrm{~L}^{2} /\left(\mathrm{E}_{\text {balok }} * \mathrm{I}_{\mathrm{xc}}\right)=0.00233 \mathrm{~m} \quad$ ke bawah

Lendutan akibat beban angin $(\mathrm{EW})$

$\mathrm{Q}_{\mathrm{EW}}=1.008 \mathrm{kN} / \mathrm{m}$

$\mathrm{d}=5 / 384 * \mathrm{Q}_{\mathrm{EW}} * \mathrm{~L}^{4} /\left(\mathrm{E}_{\text {balok }} * \mathrm{I}_{\mathrm{xc}}\right) \quad=0.00040 \mathrm{~m} \quad$ ke bawah

Lendutan akibat beban gempa (EQ)

$\mathrm{d}=5 / 384 * \mathrm{Q}_{\mathrm{EQ}} * \mathrm{~L}^{4} /\left(\mathrm{E}_{\text {balok }} * \mathrm{I}_{\mathrm{xc}}\right)=0.00136 \mathrm{~m}$ ke bawah

Lendutan maksimum yang diijinkan $\quad \mathrm{d}=\mathrm{L} / 300=0.0800 \quad \mathrm{~m}$

Tabel 12. Lendutan Yang Terjadi Akibat Kombinasi Pembebanan

Lendutan maksimum pada balok komposit akibat kombinasi pembebanan terjadi pada

kombinasi 4 yakni sebesar $0.01258 \mathrm{~m}<\boldsymbol{L} / \mathbf{3 0 0}(\boldsymbol{O K})$ 


\section{Tinjauan Ultimit Balok Prategang}

Gaya prestress efektif (setelah loss of prestress), $\mathrm{P}_{\mathrm{eff}} \quad=4039.06 \mathrm{Kn}$

Tegangan efektif baja prestress, $\mathrm{f}_{\mathrm{eff}}=\mathrm{P}_{\mathrm{eff}} / \mathrm{A}_{\mathrm{ps}} * 10-3=1136.7 \mathrm{MPa}$

Rasio luas penampang baja prestress, $r_{p} \quad=A_{p s} / A_{c}=0.004946$

Section Properties : $\quad B_{\text {eff }}=1.21 \mathrm{~m} \quad \mathrm{~h}=1.60 \mathrm{~m} \quad \mathrm{~h}_{\mathrm{o}}=0.20 \mathrm{~m}$

Tinggi total balok prategang, $\quad \mathrm{H}=\mathrm{h}+\mathrm{h}_{\mathrm{o}}=1.80 \mathrm{~m}$

$\mathrm{L} / \mathrm{H}=13.333 \mathrm{~m}<35(\mathrm{OK})$

$\mathrm{f}_{\mathrm{ps}}=\mathrm{f}_{\mathrm{eff}}+150+\mathrm{f}_{\mathrm{c}}{ }^{\prime} /\left(100 * \rho_{\mathrm{p}}\right) \quad=1370.6 \mathrm{MPa}$

$\mathrm{f}_{\mathrm{ps}}=\mathrm{f}_{\text {eff }}+400 \quad=1536.7 \mathrm{MPa}$

$\mathrm{f}_{\mathrm{ps}}=0.8 * \mathrm{f}_{\mathrm{py}} \quad=1264 \mathrm{MPa}$

Diambil kuat leleh baja prategang, $\quad \mathrm{f}_{\mathrm{ps}}=1264.0 \mathrm{MPa}$

Untuk, $\mathrm{f}_{\mathrm{c}}^{\prime}=41.5 \mathrm{MPa}$

$$
b_{1}=0.85-0.05 *\left(f_{c}^{\prime}-30\right) / 7=0.768
$$

Letak titik berat tendon baja prategang terhadap alas balok, $\quad \mathrm{z}_{\mathrm{o}}=0.175 \mathrm{~m}$

Tinggi efektif balok, $\quad \mathrm{d}=\mathrm{h}+\mathrm{h}_{\mathrm{o}}-\mathrm{z}_{\mathrm{o}}=1.63 \mathrm{~m}$

Kuat leleh baja prategang, $\quad \mathrm{f}_{\mathrm{ps}}=1264000 \mathrm{kPa}$

Gaya tarik pada baja prestress, $\mathrm{T}_{\mathrm{s}}=\mathrm{A}_{\mathrm{ps}} * \mathrm{f}_{\mathrm{ps}}=4491.24 \mathrm{kPa}$

Diperkirakan, $\mathrm{a}<\left(\mathrm{h}_{0}+\mathrm{h}_{1}\right) \quad \mathrm{h}_{0}+\mathrm{h}_{1}=0.325 \mathrm{~m}$

Gaya tekan beton, $\quad \mathrm{C}_{\mathrm{c}}=\left[\mathrm{B}_{\mathrm{eff}} * \mathrm{~h}_{\mathrm{o}}+\mathrm{b} 1 *\left(\mathrm{a}-\mathrm{h}_{\mathrm{o}}\right)\right] * 0.85 * \mathrm{f}_{\mathrm{c}}{ }^{\prime}$ $\mathrm{C}_{\mathrm{c}}=\mathrm{T}_{\mathrm{s}}$

maka, $\mathrm{a}=\left[\mathrm{T}_{\mathrm{s}} /\left(0.85 * \mathrm{f}_{\mathrm{c}}{ }^{\prime}\right)-\mathrm{B}_{\mathrm{eff}} * \mathrm{~h}_{\mathrm{o}}\right] / \mathrm{b}_{1}+\mathrm{h}_{\mathrm{o}}=0.2315 \mathrm{~m}$

$$
\mathbf{a}<\mathrm{h}_{0}+\mathrm{h}_{1} \text { perkiraan benar }(\mathrm{OK})
$$

Jarak garis netral terhadap sisi atas, $\quad \mathrm{c}=\mathrm{a} / \mathrm{b}_{1}=0.301 \mathrm{~m}$

Regangan baja prestress, eps $=0.003 *(\mathrm{~d}-\mathrm{c}) / \mathrm{c}$

$$
=0.0132<0.03(\mathbf{O K} !)
$$

Gaya internal tekan beton, $\quad \mathrm{C}_{\mathrm{c}}=\mathrm{S}\left[\mathrm{A}_{\mathrm{i}} * 0.85 * \mathrm{f}_{\mathrm{c}}{ }^{\prime}\right]$

Momen nominal,

$$
\mathrm{M}_{\mathrm{n}}=\mathrm{S}\left[\mathrm{A}_{\mathrm{i}} * 0.85 * \mathrm{f}_{\mathrm{c}}{ }^{\prime} * \mathrm{y}_{\mathrm{i}}\right]
$$

\begin{tabular}{|c|c|c|c|c|c|c|}
\hline $\begin{array}{l}\text { Lebar } \\
(\mathrm{m})\end{array}$ & $\begin{array}{l}\text { Tinggi } \\
\text { (m) }\end{array}$ & $\begin{array}{l}\text { Luas } \\
\left(\mathrm{m}^{2}\right)\end{array}$ & Gaya kN & $\begin{array}{l}\text { Lengan terhadap pusa } \\
\text { baja prestress }\end{array}$ & $\mathrm{y}$ & $\begin{array}{l}\text { Momen } \\
(\mathrm{kNm})\end{array}$ \\
\hline 1.21 & 0.2000 & 0.2410 & 8502.65 & $\mathrm{y}=\mathrm{d}-\mathrm{h}_{0} / 2$ & 1.525 & 12966.54 \\
\hline 0.55 & 0.0315 & 0.0173 & 610.99 & $\mathrm{y}=\mathrm{d}-\mathrm{h}_{0} / 2-\left(\mathrm{a}-\mathrm{h}_{\mathrm{o}}\right) / 2$ & 1.409 & 861.05 \\
\hline & \multicolumn{2}{|c|}{$\mathrm{C}_{\mathrm{c}}=\mathrm{T}_{\mathrm{s}}=$} & 9113.64 & Momen Nominal & $I_{n}=$ & 13827.59 \\
\hline
\end{tabular}

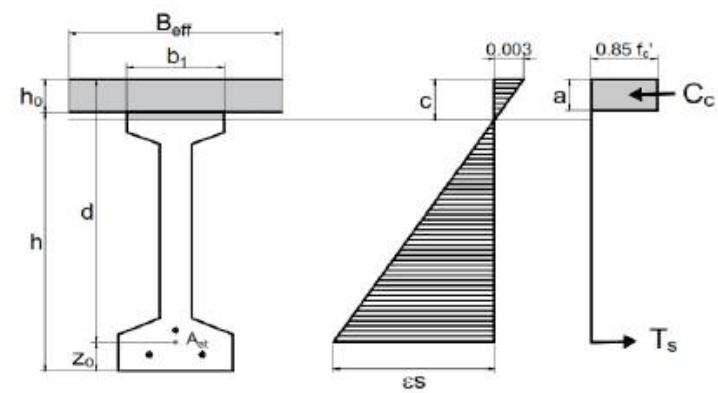

Gambar 12 Kapasitas momen ultimit balok

Tabel 13. Gaya tekan beton dan momen nominal

Faktor reduksi kekuatan lentur,

Kapasitas momen ultimit balok prestress,

$$
\begin{array}{ll}
\mathrm{f} & =0.80 \\
\mathrm{f} * \mathrm{M}_{\mathrm{n}} & =11062.07 \mathrm{kNm}
\end{array}
$$


Momen ultimit balok dapat dilihat dalam tabel berikut ini :

Tabel 14. Resume momen balok

\begin{tabular}{|c|c|c|c|c|c|c|}
\hline \multirow{3}{*}{ Aksi / Beban } & \multirow{3}{*}{\multicolumn{2}{|c|}{$\begin{array}{l}\text { Faktor } \\
\text { Beban } \\
\text { Ultimit }\end{array}$}} & \multirow{2}{*}{\multicolumn{2}{|c|}{$\begin{array}{l}\text { Daya Layan } \\
\text { Momen }\end{array}$}} & \multicolumn{2}{|c|}{ Kondisi Ultimit } \\
\hline & & & & & \multicolumn{2}{|c|}{ Momen Ultimit } \\
\hline & & & $\mathrm{M}$ & $(\mathrm{kNm})$ & $\mathrm{Mu}$ & $(\mathrm{kNm})$ \\
\hline \multicolumn{7}{|l|}{ A. Aksi Tetap } \\
\hline Berat sendiri & $\mathrm{K}_{\mathrm{MS}}$ & 1.3 & $\mathrm{M}_{\mathrm{MS}}$ & 1846.28 & $\mathrm{~K}_{\mathrm{MS}} * \mathrm{M}_{\mathrm{MS}}$ & 2400.16 \\
\hline Beban Mati Tambahan & $\mathrm{K}_{\mathrm{MA}}$ & 2.0 & $\mathrm{M}_{\mathrm{MA}}$ & 355.015 & $\mathrm{~K}_{\mathrm{MA}} * \mathrm{M}_{\mathrm{MA}}$ & 710.03 \\
\hline Susut dan Rangkak & $\mathrm{K}_{\mathrm{SR}}$ & 1.0 & $\mathrm{M}_{\mathrm{SR}}$ & 20.857 & $\mathrm{~K}_{\mathrm{SR}} * \mathrm{M}_{\mathrm{SR}}$ & 20.857 \\
\hline Prategang & $\mathrm{K}_{\mathrm{PR}}$ & 1.0 & $\mathrm{M}_{\mathrm{PR}}$ & -2163.5 & $\mathrm{~K}_{\mathrm{PR}} * \mathrm{M}_{\mathrm{PR}}$ & -2163.5 \\
\hline \multicolumn{7}{|l|}{ B. Aksi Transien } \\
\hline Beban Lajur "D" & $\mathrm{K}_{\mathrm{TD}}$ & 2.0 & $\mathrm{M}_{\mathrm{TD}}$ & 1942.25 & $\mathrm{~K}_{\mathrm{TD}} * \mathrm{M}_{\mathrm{TD}}$ & 3884.49 \\
\hline Gaya Rem & $\mathrm{K}_{\mathrm{TB}}$ & 2.0 & $\mathrm{M}_{\mathrm{TB}}$ & 83.0439 & $\mathrm{~K}_{\mathrm{TB}} * \mathrm{M}_{\mathrm{TB}}$ & 166.09 \\
\hline \multicolumn{7}{|l|}{ C. Aksi Lingkungan } \\
\hline Pengaruh Temperatur & $\mathrm{K}_{\mathrm{ET}}$ & 1.2 & $\mathrm{M}_{\mathrm{ET}}$ & 681.986 & $\mathrm{~K}_{\mathrm{ET}} * \mathrm{M}_{\mathrm{ET}}$ & 818.38 \\
\hline Beban Angin & $\mathrm{K}_{\mathrm{EW}}$ & 1.2 & $\mathrm{M}_{\mathrm{EW}}$ & 72.576 & $\mathrm{~K}_{\mathrm{EW}} * \mathrm{M}_{\mathrm{EW}}$ & 87.09 \\
\hline Beban Gempa & $\mathrm{K}_{\mathrm{EQ}}$ & 1.0 & $\mathrm{M}_{\mathrm{EQ}}$ & 245.389 & $\mathrm{~K}_{\mathrm{EQ}} * \mathrm{M}_{\mathrm{EQ}}$ & 245.39 \\
\hline
\end{tabular}

Kapasitas momen balok,

Tabel 15. Kombinasi momen ultimit

\begin{tabular}{|c|c|c|c|c|c|c|c|c|c|c|c|}
\hline Momen & Berat Sen & Mati Tamb & Sust-Rang & Prategang & Lajur "D" & Rem & Temperatur & Angin & Gempa & Lendutan & \\
\hline Ultimit & $\mathrm{K}_{\mathrm{MS}}{ }^{*} \mathrm{M}_{\mathrm{MS}}$ & $\mathrm{K}_{M A} * \mathrm{M}_{\mathrm{MA}}$ & $\mathrm{K}_{S R}{ }^{*} \mathrm{M}_{S R}$ & $\mathrm{~K}_{\mathrm{PR}}{ }^{*} \mathrm{M}_{\mathrm{PR}}$ & $\mathrm{K}_{\mathrm{TD}} \mathrm{M}_{\mathrm{TD}}$ & $\mathrm{K}_{\mathrm{TB}}{ }^{*} \mathrm{M}_{\mathrm{TB}}$ & $\mathrm{K}_{\mathrm{ET}} * \mathrm{M}_{\mathrm{ET}}$ & $\mathrm{K}_{E \mathrm{E}} * \mathrm{M}_{\mathrm{EW}}$ & $\mathrm{K}_{\mathrm{EO}}^{*} \mathrm{M}_{\mathrm{EO}}$ & KOMB & Keterengan \\
\hline \multicolumn{12}{|c|}{ KOMBINASI - 1} \\
\hline $\mathrm{M}_{u}$ & 2400.16 & 710.03 & -20.86 & -2163.54 & 3884.49 & 166.09 & & & & 5018.09 & $<M_{H}$ \\
\hline \multicolumn{12}{|c|}{ KOMBINASI - 2} \\
\hline $\mathrm{M}_{\mathrm{u}}$ & 2400.16 & 710.03 & -20.86 & -2163.54 & 3884.49 & 166.09 & 818.38 & & & 5836.47 & $<M_{0}$ \\
\hline \multicolumn{12}{|c|}{ KOMBINASI - 3} \\
\hline $\mathrm{M}_{u}$ & 2400.16 & 710.03 & -20.86 & -2163.54 & 3884.49 & 166.09 & & 87.09 & & 5105.18 & $<M_{\mathrm{u}}$ \\
\hline \multicolumn{12}{|c|}{ KOMBINASI - 4} \\
\hline $\mathrm{Mu}_{\mathrm{u}}$ & 2400.16 & 710.03 & -20.86 & -2163.54 & 3884.49 & & 818.38 & 87.09 & & 5757.47 & $<M_{\mathrm{u}}$ \\
\hline \multirow{2}{*}{\multicolumn{12}{|c|}{ KOMBINASI - 5}} \\
\hline $\mathrm{M}_{\mathrm{u}}$ & & 710.03 & -20.86 & -2163.54 & & & & & 245.39 & 1212.89 & $<M$ \\
\hline
\end{tabular}

Kombinasi momen ultimit maksimum pada balok komposit akibat kombinasi pembebanan terjadi pada kombinasi 4 yakni sebesar $5836.47 \mathrm{kNm}<$ kapasitas momen balok sebesar $11062.07 \mathrm{kNm}$.

\section{Kesimpulan}

Dari hasil desain dan analitis yang telah dilakukan pada tulisan ini didapat beberapa kesimpulan, yaitu sebagai berikut:

- Untuk jembatan bentang $24 \mathrm{~m}$ dibutuhkan girder prategang yang ideal dengan tinggi 160 $\mathrm{cm}$.

- Berdasarkan SNI 17252016 pembebanan untuk jembatan prategang bentang $24 \mathrm{~m}$ dibutuhkan jumlah tendon sebanyak 3 buah dengan tiap tendon terdiri dari 12 strand dengan diameter $12.7 \mathrm{~mm}$.

- Kehilangan prategang yang digunakan pada asumsi awal desain sebesar 30\% dan setelah perhitungan mendapatkan kehilangan prategang sebesar $24.52 \%$ pada balok girder.

\section{Daftar Pustaka}

Departemen Pekerjaan Umum. (2016). Pembebanan untuk Jembatan. Jakarta: Badan Standarisasi Nasional.

Departemen Pekerjaan Umum. (2002). Tata Cara Perhitungan Struktur Beton untuk Bangunan Gedung. Jakarta: Badan Standarisasi Nasional. 
Hadipratomo, W. (2008). Analisis dan Desain Struktur Beton Prategang. Bandung: PT. Danamartha Sejahtera Utama.

Budiadi, A. (2008). Desain Praktis Beton Prategang. Yogyakarta: CV. Andi offset.

Supriyadi, B., \& Muntohar, S.A. (2007). Jembatan. Yogyakarta: Beta offset.

Kusuma, G., \& Vis, W.C. (1997). Dasar-dasar Perencanaan Beton Bertulang. Jakarta: Erlangga.

Nawy, E. G. (2001). Beton Prategang Suatu Pendekatan Mendasar. Jakarta: Erlangga.

Prestressed Concrete Institute. (2010). PCI Design Handbook - Precast and Prestressed Concrete. Chicago: Prestressed Concrete Institute.

Ilham, M. N. (2008). Perhitungan Balok Prategang (PC-I Girder). Yogyakarta. 